\title{
Chronic inflammatory demyelinating polyneuropathy in two siblings
}

\author{
AAWM GABREËLS-FESTEN, ATM HAGEMAN, FJM GABREËLS, EMG JOOSTEN, \\ WO RENIER, CMR WEEMAES, HJ TER LAAK
}

From the Institutes of Neurology, Pediatrics and Submicroscopic Morphology, St Radboud University Hospital, Nijmegen, The Netherlands

SUMMARY A familial occurrence of chronic inflammatory demyelinating polyneuropathy is reported. The diagnostic problems in distinguishing the progressive form of this disease in childhood from hereditary motor and sensory neuropathy types I and III are discussed. Criteria for a definite diagnosis of chronic inflammatory demyelinating polyneuropathy are proposed.

Chronic inflammatory demyelinating polyneuropathy is a disorder in which clinical and laboratory investigations suggest a primarily inflammatory demyelinating process. The following diagnostic criteria of chronic inflammatory demyelinating polyneuropathy have been proposed: ${ }^{12}$

(1) presence of a sensorimotor polyneuropathy involving proximal as well as distal limb structures,

(2) a slow onset and a steadily progressive or relapsing-remitting course,

(3) elevated cerebrospinal fluid (CSF) protein content without an increase of mononuclear cells,

(4) marked slowing of nerve conduction velocity,

(5) sural nerve biopsy showing segmental demyelination with or without onion bulb formation and perivascular or diffuse infiltrates of mononuclear cells,

(6) absence of evidence of any associated or systemic disease, intoxication, malignancy or monoclonal gammopathy.

There is evidence of disturbed humoral and cellular immunological mechanisms in chronic inflammatory demyelinating polyneuropathy, ${ }^{3-7}$ and therapy with corticosteroids or plasmapheresis has been shown to cause improvement. ${ }^{689}$

Two investigations have suggested that HLAlinked genetic factors may influence susceptibility to chronic inflammatory demyelinating polyneuropathy. ${ }^{1011}$ Nevertheless, a familial occurrence

Address for reprint requests: Dr Gabreëls-Festen, Institute of Neurology, St Radboud University Hospital, PO Box 9101, 6500 HB Nijmegen, The Netherlands.

Received 30 November 1984 and in revised form 22 May 1985. Accepted 28 May 1985 of chronic inflammatory demyelinating polyneuropathy has not yet been reported. We present the occurrence of chronic inflammatory demyelinating polyneuropathy in two sibs.

Case reports

A normally intelligent girl, aged 9 years, eldest child 꾸을 healthy unrelated parents, was admitted to our department because of difficulty in walking. Pregnancy, delivery a. postnatal development were normal. She received the rod-음 tine diphtheria, pertussis, tetanus and poliomyelitis vacegnations between the 3 rd and 12th month without showi complications. At the age of 14 months she could walk wi out support, but gait was awkward. Gradually, she devetoped pes cavus and scoliosis.

On examination, muscle strength was poor in all limbs $\square$ and muscle wasting was present. She had an equine gait. Slight sensory loss was detectable, particularly in distal lower limbs. Tendon reflexes were absent. Nerves were not palpably thickened. Muscle and nerve biopsy was per-응 formed. A follow-up study of six years revealed a slow $\varrho$ progression of the polyneuropathy and an increasing sco- $\overrightarrow{\bar{O}}$ liosis.

Two years later, a younger sister was admitted to our $\bar{\partial}$ department. This girl, the third child, aged 4 years 9 months, suffered from the same walking difficulties as her sister. Pregnancy, delivery and postnatal development had been normal, and she received the normal vaccinations without com- 0 plications. She could walk without support at the age of $14 \dot{\sigma}$ months, but gait remained clumsy. On examination, she had poor muscle strength, wasting of muscle and a slight sensory $\delta$ loss in distal limbs. She had a slight scoliosis. Nerves were not palpably thickened.

\section{Family investigation}

There was no history of familial polyneuropathy. The mother showed slightly elevated arches but no muscle weak- $N$ ness or reflex changes. Father and the second (female) child 5 


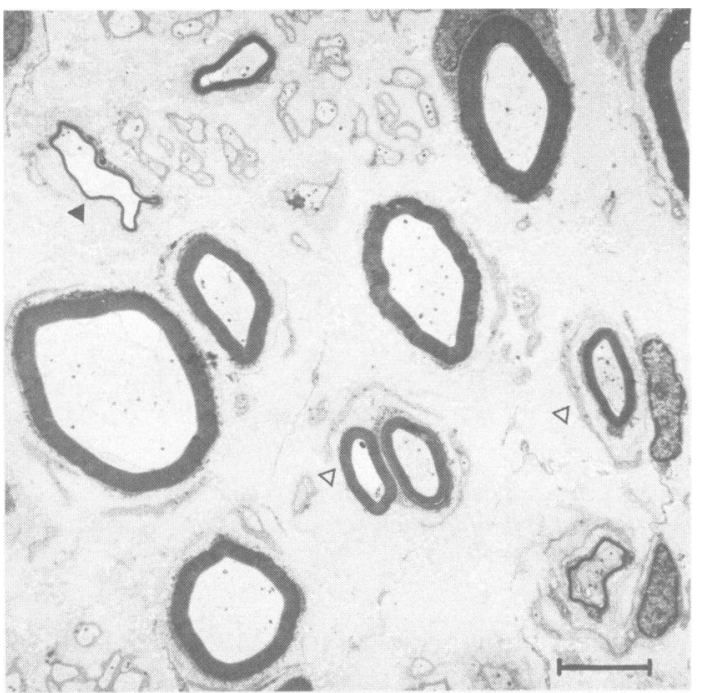

Fig 1 Case 2. Sural nerve showing remyelinated axons ( $\Delta$ ) and onion bulbs $(\triangle)$ (Ultrathin Epon section, bar $=5 \mu \mathrm{m}$ ).

had neither abnormalities on neurological examination. Maximal motor conduction velocities of both parents and the healthy sister were completely normal (table 1). Two maternal sisters had slightly high arches but they too showed no abnormalities on neurological and electrophysiological examination. A child of the sister of mother's mother had a scoliosis but she showed normal muscle strength and normal reflexes. Nerve conduction velocity studies and electromyography yielded no abnormalities. Autoimmune diseases occurred in the paternal family as well as in the maternal family. Two relatives suffered from rheumatoid arthritis, one relative suffered from ankylosing spondylitis and regional enteritis.

\section{Laboratory investigations}

Blood and urine of both patients were investigated but no abnormalities were found. There were no signs of metabolic or endocrine disorders, nor signs of intoxication or deficiency. Muscle enzymes were normal. Lysosomal enzymes were also normal. Serological and bacteriological investigations all were negative. CSF protein content of patient 1 was increased $(630 \mathrm{mg} / \mathrm{l}$, normal up to 350$)$ without an increase in cells. CSF of patient 2 was not examined.

\section{Electrophysiological examination}

Both girls showed decreased maximal motor conduction velocities, especially in the lower limbs (table 1). Sensory potentials of the sural nerve could not be elicited.

\section{Immunological examination}

The concentrations of serum immunoglobulins and of the IgG subclasses were normal, in accordance with age. The percentages of $B$ lymphocytes and $T$ lymphocytes were normal. $T$ cell subset analyses revealed a normal proportion of $\mathrm{OKT}_{4} / \mathrm{OKT}_{8} \mathrm{~T}$ cells. Results of lymphocyte stimulation in vitro with phytohaemagglutinin and pokeweed mitogen were normal, as were the total haemolytic complement contents.

Patient 1 had the following HLA phenotype $\mathrm{A}_{2} \mathrm{~B}_{7} \mathrm{DR}_{5} / \mathrm{A}_{11} \mathrm{Bw}_{16} \mathrm{DR}_{4}$ and patient $2 \mathrm{Aw}_{30} \mathrm{~B}_{5} \mathrm{DR}_{6} /$ $\mathrm{A}_{11} \mathrm{Bw}_{16} \mathrm{DR}_{4}$. The HLA phenotypes of the parents and the healthy sister were: father $A_{11} B_{27} D R_{1} / A_{11} B w_{16} D R_{4}$, mother $\mathrm{A}_{2} \mathrm{~B}_{7} \mathrm{DR}_{5} / \mathrm{Aw}_{30} \mathrm{~B}_{5} \mathrm{DR}_{6}$, sister $\mathrm{A}_{2} \mathrm{~B}_{7} \mathrm{DR}_{5} /$ $A_{11} B_{27} D R_{1}$. Thus our patients were haplo-identical for the haplotype received from the father.

\section{Morphological examination}

Midcalf sural nerve biopsy and soleus muscle biopsy of both patients were performed for light and electron microscopic examination, according to our previously described techniques. $^{12}$

Cross sections of the sural nerve revealed sporadically demyelinated and occasionally remyelinated fibres, and slight onion bulb formation (fig 1). Some clusters of small regenerated and remyelinated axons inside onion bulb structures were seen, especially in the elder girl. Infrequently, fibres showed an increased myelin thickness, which in longitudinal section appeared to be local thickenings of the myelin sheath. Scattered foci of mononuclear cells were found, particularly around some endo- and epineurial blood vessels. In each biopsy, four or five infiltrates of lymphocytic cells could be distinguished in transverse and longitudinal sections randomly made of $1 \mathrm{~cm}$ of the sural nerve (figs 2 and 3 ). Teased fibre studies confirmed a process of segmental deand remyelination (table 2 ).

Number and diameter of myelinated fibres were measured on electron microscopic photographs $(\times 1700)$ with a Zeiss TGZ-3 particle size analyser. The histograms of diameters of myelinated fibres showed a unimodal pattern, with nearly absent large fibres: $6 \%$ (patient 1 ) respectively $4 \%$ (patient 2) of the myelinated fibres showed a diameter of more than $8 \mu \mathrm{m}$ (normal $18 \%$, SD $6 \%$ ). Density of myelinated fibres was decreased (patient 1) or low normal (patient 2), partly owing to an increase of total transverse fascicular area (TTFA) (table 2).

Muscle biopsy sections revealed in both cases a preponderance of type I fibres, which accounted for $90 \%$ of all the muscle fibres (normal $65 \%$ ). Both cases showed some intrafascicular infiltration of mononuclear cells, which reacted partly positive with AcP-ase (histiocytes) and negative with AMP-ase (probably T lymphocytes).

Table 1 Motor conduction velocities $(\mathrm{m} / \mathrm{s})$ in median and peroneal nerve

\begin{tabular}{llllll}
\hline & Case 1 & Case 2 & Mother & Father & Sister \\
\hline Median nerve (N, 43-77) & 34 & 41 & 47 & 45 & 52 \\
Peroneal nerve (N, 41-58) & 23 & 27 & 47 & 45 \\
\hline $\mathrm{N}=$ normal. & & &
\end{tabular}

$\mathrm{N}=$ normal. 


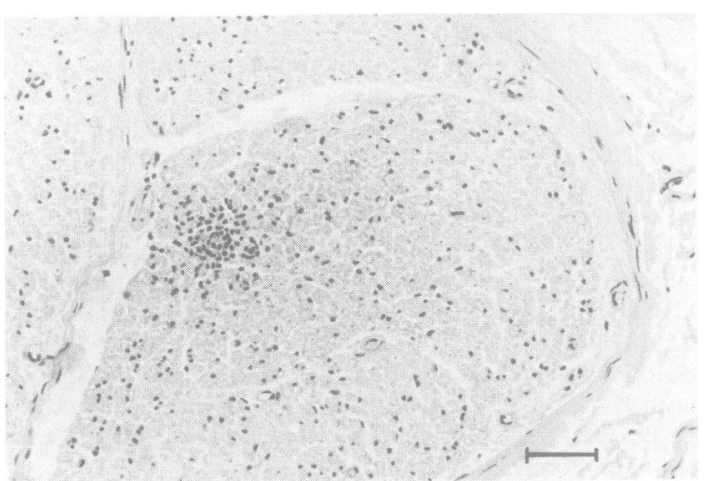

Fig 2 Case 1. Sural nerve showing mononuclear cell infiltration in endoneurium (paraffin section, Haematoxylin and Eosin, bar $=50 \mu \mathrm{m}$ ).

\section{Discussion}

The children described fulfil the diagnostic criteria of chronic inflammatory demyelinating polyneuropathy ${ }^{12}$ mentioned in the introduction.

In the literature there are several reports of chronic inflammatory demyelinating polyneuropathy in childhood. ${ }^{213-22}$ Most of the described cases ran a relapsing course; some cases exhibited a chronic progressive course. Both forms are considered variants of chronic inflammatory demyelinating polyneuropathy. ${ }^{19}$ A relapsing/remitting course is a strong argument for the diagnosis chronic inflammatory demyelinating polyneuropathy, as other polyneuropathies which can exhibit a recurrent course $^{23}$ can generally be excluded by careful clinical, biochemical and/or morphological investigations. However, it may be difficult to assess a remitting course in young children because natural motor development can blurr the course of the disease.

Special diagnostic problems arise if the illness starts early in life, with slow progression after an insidious onset. In these cases differentiation has to be made from hereditary motor and sensory neuropathy (HMSN) type III or HMSN type I. ${ }^{24}$ An onset in the first decade of life is obligatory in HMSN type $\mathrm{III}^{25}$

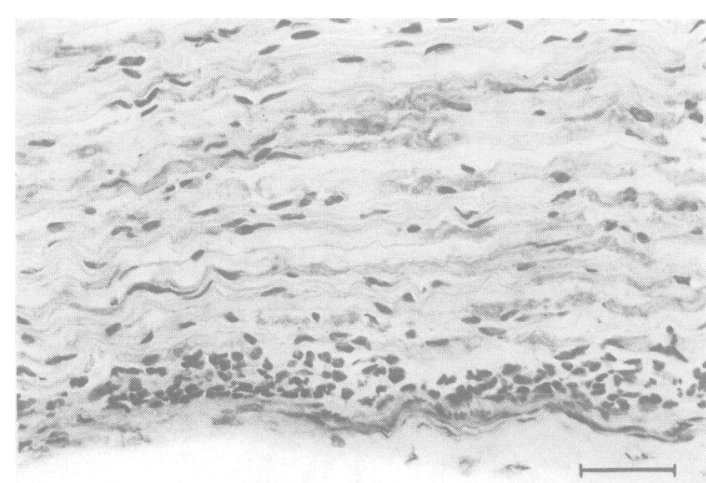

Fig 3 Case 2. Sural nerve showing subperineurial mononuclear cell infiltration (cryostat section, Haematoxylin and Eosin, bar $=50 \mu \mathrm{m}$ ).

and occurs in the majority of HMSN type I cases, ${ }^{26} \vec{\circ}$ even in the autosomal recessive form. ${ }^{27}$

A raised CSF protein is common in HMSN type $\stackrel{\omega}{\omega}$ III. ${ }^{25}$ In HMSN type I, although usually normal or only slightly raised CSF protein values are found,? several reports have mentioned substantially elevated $\vec{\oplus}$ CSF protein levels. ${ }^{2128}$

Mononuclear cell infiltrates are considered $\frac{0}{\mathrm{a}} \mathrm{F}$ pathologic hallmark in chronic inflammatory demy $N$ linating polyneuropathy. ${ }^{129}$ As such, they can be the only sign in distinguishing chronic progressive cases of chronic inflammatory demyelinating pol\$ 7 neuropathy from HMSN type I or HMSN type III. . $^{4} \frac{\mathrm{O}}{\mathrm{C}}$ Theoretically, the possibility exists that mononuclege cell infiltrates could occur in hereditary demyelinatiog disease merely as an incidental response to the myel$\vec{i}$ breakdown. But neither in the literature to ouro knowledge, nor from our own experience covering $58{ }^{\circ} \mathrm{C}$ HMSN type I and 12 HMSN type III sural nerve biopsies, have inflammatory signs been found.

Perivascular or diffuse infiltrates of mononuclear cells are recognised in only a limited number of nerve biopsies of chronic inflammatory demyelinating polyneuropathy, ranging from $0 \%$ to $53 \cdot 8 \%{ }^{1}$ Inflammatory lesions are seen more often in the proximal parts of the nerve (nerve roots, trunks, plexuses)

Table 2 Quantitative findings in sural nerve

\begin{tabular}{|c|c|c|c|c|c|c|c|}
\hline \multirow{2}{*}{$\begin{array}{l}\text { Case } \\
\text { No }\end{array}$} & \multirow{2}{*}{$\begin{array}{l}\text { Age } \\
\text { (yr, months) }\end{array}$} & \multirow{2}{*}{$\begin{array}{l}\text { Myelinated fibre } \\
\text { density }\end{array}$} & \multirow{2}{*}{$\begin{array}{l}T T F A^{\dagger} \\
(\mathrm{mm})\end{array}$} & \multicolumn{4}{|c|}{ Teased fibre preparations* } \\
\hline & & & & Number of fibres & $A$ & $E$ & $C D F$ \\
\hline $\begin{array}{l}1 \\
2 \\
\text { Controls }(n=12)\end{array}$ & $\begin{array}{l}9,0 \\
4,9 \\
4,0-10,0\end{array}$ & $\begin{array}{l}5,600 \\
8,600 \\
13,000(\text { SD } 1,700)\end{array}$ & $\begin{array}{l}1.44 \\
1 \cdot 18 \\
0.80(\text { SD } 0 \cdot 14)\end{array}$ & $\begin{array}{l}28 \\
72\end{array}$ & $\begin{array}{r}75 \cdot 0 \\
91 \cdot 7 \\
>98\end{array}$ & $\begin{array}{l}0 \\
0 \\
0\end{array}$ & $\begin{array}{l}25 \\
8 \cdot 3 \\
<2\end{array}$ \\
\hline
\end{tabular}

* Capitals refer to the condition of the teased fibre: $\mathrm{A}=$ normal appearance; $\mathrm{C}=$ widening of nodal gap; $\mathrm{D}=$ segmental demyelination; $\mathrm{E}$ = axonal degeneration with linear rows of myelin balls; $F=$ segmental or paranodal remyelination. †TTFA $=$ total transverse fascicular area. 
only available by necropsy. ${ }^{130}$ So the chance of finding infiltrates in the distally located portion of the nerve taken by biopsy is limited. It is obvious that a number of chronic inflammatory demyelinating polyneuropathy will remain undiagnosed because inflammatory signs will not always be found. ${ }^{731}$

Several indications exist that genetic factors may play a role in the pathogenesis of chronic inflammatory demyelinating polyneuropathy. Skeletal abnormalities and/or (sub)clinical signs suggestive of polyneuropathy have been mentioned in relatives of chronic inflammatory demyelinating polyneuropathy patients. ${ }^{18223233}$ Dyck et al ${ }^{33}$ suggested a genetic susceptibility to inflammatory demyelinating processes in kindreds with hereditary motor and sensory neuropathy. Therefore, they recommended a therapeutic trial with prednisone for patients suffering from a HMSN type I syndrome with increased levels of CSF protein. Corticosteroid medication in patients who definitely have familial HMSN type I does not seem to be justified. ${ }^{34}$

Steinman $e^{a l^{35}}$ have shown different suspectibility between inbred strains of rats to experimental allergic neuritis: the experimental model of acute and chronic inflammatory demyelinating polyneuropathy (among others Waksman et $a^{36}$ ). Stewart et al ${ }^{10}$ and Adams et al ${ }^{11}$ demonstrated in preliminary studies that chronic inflammatory demyelinating polyneuropathy, like other organ-specific autoimmune diseases, is probably associated with certain antigens of the HLA system. In spite of these indications of a genetic factor, a familial occurrence of chronic inflammatory demyelinating polyneuropathy has not been described up to now. Instead, a kinship history of neuropathy has even been put forward as a criterion against the diagnosis of chronic inflammatory demyelinating polyneuropathy. ${ }^{9}$

The occurrence of chronic inflammatory demyelinating polyneuropathy in our two sibs strongly supports the view of a genetic disposition. It is unlikely that the maternal factor or some exogenous (such as infectious) agent is responsible for the disease in our patients, because there is a healthy sister between our two patients, and there is a gap of $51 / 2$ years in the times of disease onset. An autosomal recessive transmission is theoretically possible (healthy parents, two female sibs), but unlikely. Considering the nature of the disease, a multifactorial inheritance is most probable. HLA antigens could be one of the genetic factors in this polygenic disease. Our patients were haplo-identical for the haplotype received from the father, the healthy sister having a different haplotype.

Our patients did not receive prednisone therapy, azathioprine or plasmapheresis, because the neurological disability was judged insufficiently severe to justify the risks of such a prolonged treatment. ${ }^{9}$
The following criteria might be particularly useful in distinguishing childhood chronic inflammatory demyelinating polyneuropathy from other demyelinating polyneuropathies at young age: a relapsing/remitting course, remission directly related to pharmacotherapy, mononuclear cell infiltrates in nerve biopsy specimen. Presence of at least one of these criteria is obligatory for making a definite diagnosis of chronic inflammatory demyelinating polyneuropathy.

From our study it can be concluded that in chronic progressive demyelinating polyneuropathy of unknown aetiology with raised CSF protein a careful search should be made for inflammatory signs in nerve biopsy, even if there is a kinship history of polyneuropathy.

\section{References}

${ }^{1}$ Dyck PJ, Lais AC, Ohta M, Bastron JA, Okazaki $\mathrm{H}$, Groover RV. Chronic inflammatory polyradiculoneuropathy. Mayo Clin Proc 1975;50:621-37.

${ }^{2}$ Prineas JW, McLeod JG. Chronic relapsing polyneuritis. J Neurol Sci 1976;27:427-58.

${ }^{3}$ Abramsky O, Webb C, Teitelbaum D, Arnon R. Cellmediated immunity to neural antigens in idiopathic polyneuritis and myeloradiculitis. Neurology (Minneap) 1975;25:1154-9.

${ }^{4}$ Dalakas MC, Engel WK. Immunoglobulin and complement deposits in nerves of patients with chronic relapsing polyneuropathy. Arch Neurol 1980;37:637-40.

${ }^{5}$ Dalakas MC, Houff SA, Engel WK, Madden DL, Sever JL. CSF "monoclonal" bands in chronic relapsing polyneuropathy. Neurology (Minneap) 1980;30:864-7.

${ }^{6}$ Dalakas MC, Engel WK. Chronic relapsing (dysimmune) polyneuropathy: pathogenesis and treatment. Ann Neurol 1981;9(suppl):134-45.

${ }^{7}$ Dyck PJ, Arnason B. Chronic inflammatory demyelinating polyradiculoneuropathy. In: Dyck PJ, Thomas PK, Lambert EH, Bunge R, eds. Peripheral Neuropathy. Philadelphia: WB Saunders and Co, 1984:2101-14.

${ }^{8}$ Austin JH. Recurrent polyneuropathies and their corticosteroid treatment with five-year observations of a placebo-controlled case treated with corticotrophin, cortisone, and prednisone. Brain 1958;81:157-94.

${ }^{9}$ Dyck PJ, O'Brien PC, Oviatt KF, et al. Prednisone improves chronic inflammatory demyelinating polyradiculoneuropathy more than no treatment. $\mathrm{Ann} \mathrm{Neu}$ rol 1982;11:136-41.

${ }^{10}$ Stewart GJ. Pollard JD, McLeod JG, Wolnizer CM. HLA antigens in the Landry-Guillain-Barre syndrome and chronic relapsing polyneuritis. Ann Neurol 1978; 4:285-9.

${ }^{11}$ Adams D, Festenstein H, Gibson JD, et al. HLA antigens in chronic relapsing idiopathic inflammatory polyneuropathy. $J$ Neurol Neurosurg Psychiatry 1979;42:184-6.

${ }^{12}$ Joosten EMG, Krijgsman JB, Gabreëls-Festen AAWM, Gabreëls FJM, Baars PEC. Infantile globoid cell leuco- 
dystrophy (Krabbe's disease). Neuropädiatrie 1974; 5:191-209.

${ }^{13}$ Byers RK, Taft LT. Chronic multiple peripheral neuropathy in childhood. Pediatrics 1957;20:517-37.

${ }^{14}$ Chambers R, MacDermot V. Polyneuritis as a cause of "amyotonia congenita". Lancet 1957;1:397-401.

${ }^{15}$ Schaltenbrand G, Bammer $H$. Les polyradiculonévrites d'étiologie indéterminée. La clinique et le traitement des polynévrites inflammatoires ou séreuses aiguës. Rev Neurol (Paris) 1966;115:783-810.

${ }^{16}$ Tasker W, Chutorian AM. Chronic polyneuritis of childhood. J Pediatr 1969;74:699-708.

${ }^{17}$ Prineas JW. Demyelination and remyelination in recurrent idiopathic polyneuropathy. An electron microscopic study. Acta Neuropathol (Berl) 1971;18:34-57.

${ }^{18}$ Pleasure DE, Towfighi J. Onion bulb neuropathies. Arch Neurol 1972;26:289-301.

${ }^{19}$ Evans OB. Polyneuropathy in childhood. Pediatrics 1979;64:96-105.

${ }^{20}$ Colan RV, Snead III OC, Oh SJ, Benton JW Jr. Steroidresponsive polyneuropathy with subacute onset in childhood. J Pediatr 1980;97:374-7.

${ }^{21}$ Hagberg B, Lyon G. Pooled European series of hereditary peripheral neuropathies in infancy and childhood. A "correspondence work shop" report of the European Federation of Child Neurology Societies (EFCNS). Neuropediatrics 1981;12:9-17.

22 Pasternak JF, Fulling K, Nelson J, Prensky AL. An infant with chronic, relapsing polyneuropathy responsive to steroids. Dev Med Child Neurol 1982;24:504-24.

${ }^{23}$ Neundörfer B. Differentialtypologie der Polyneuritiden und Polyneuropathien. Berlin: Springer Verlag, 1973: 59-64.

${ }^{24}$ Schaumberg HH, Spencer PC, Thomas PK, eds. Disorders of Peripheral Nerves. Philadelphia: FA Davis Company, 1983.

${ }^{25}$ Dyck PJ, Lambert EH. Lower motor and primary sensory neuron diseases with peroneal muscular atrophy. I. Neurologic, genetic and electrophysiologic findings in hereditary polyneuropathies. Arch Neurol 1968; 18:603-25.

${ }^{26}$ Harding AE, Thomas PK. The clinical features of hereditary motor and sensory neuropathy types I and II. Brain 1980;103:259-80.

${ }^{27}$ Harding AE, Thomas PK. Autosomal recessive forms of hereditary motor and sensory neuropathy. $J$ Neurol Neurosurg Psychiatry 1980;43:669-78.

${ }^{28}$ Joosten EMG. De syndromen van Charcot-Marie-Tooth en van Dejerine-Sottas. Thesis, Nijmegen, 1982.

${ }^{29}$ Asbury AK, Arnason BG, Adams RD. The inflammatory lesion in idiopathic polyneuritis. Its role in pathogenesis. Medicine (Baltimore) 1969;48:173-215.

${ }^{30}$ Thomas PK, Lascelles RG, Hallpike JF, Hewer RL. Recurrent and chronic relapsing Guillain-Barré polyneuritis. Brain 1969;92:589-606.

${ }^{31}$ McLeod JG, Tuck RR, Pollard JD, Cameron J, Walsh JC. Chronic polyneuropathy of undetermined cause. $J$ Neurol Neurosurg Psychiatry 1984;47:530-5.

${ }^{32}$ Prineas J. Polyneuropathies of undetermined cause. Acta Neurol Scand (Suppl) 1970;44:31-41.

${ }^{33}$ Dyck PJ, Swanson CJ, Low PA, Bartleson JD, Lambert EH. Prednisone-responsive hereditary motor and sensory neuropathy. Mayo Clin Proc 1982;57:239-46.

${ }^{34}$ Prensky AL, Dodson WE. The steroid treatment of hereditary motor and sensory neuropathy. Neuropediatrics 1984;15:203-7.

${ }^{35}$ Steinman L, Smith ME, Forno LS. Genetic control of $\mathrm{N}$ susceptibility to experimental allergic neuritis and the immune response to $\mathrm{P}_{2}$ protein. Neurology $(N Y)$ 1981;31:950-4.

${ }^{36}$ Waksman BH. Experimental immunologic disease of the peripheral nervous system. In: Rose AS, Pearson CM. eds. Mechanisms of Demyelination. New York McGraw-Hill, 1963:170-98. 